九州大学学術情報リポジトリ

Kyushu University Institutional Repository

(E) -N-(3, 4-d ime thy li soxazo l-5-yl) $-4-((4-$ hydroxy-2-oxo-2H-chromen-3-y L)

diazenyl)Benzenesulfonamide; A New Synthetic Anti-Herpetic Agent for HSV-1

Kumar, Ashish

Department of Applied Science \& Humanities, G.L. Bajaj Institute of Technology \& Management

Brij Kishore Tiwari

Department of Applied Science \& Humanities, G.L. Bajaj Institute of Technology \& Management

Mishra, Mamta

Department of Applied Science \& Humanities, G.L. Bajaj Institute of Technology \& Management

Kumar, Navneet

Department of Applied Science \& Humanities, Inderprastha Engineering College

https://doi.org/10.5109/4480717

出版情報：Evergreen. 8 (2)，pp.351-357，2021-06. 九州大学グリーンテクノロジー研究教育センター バージョン：

権利関係 : 


\title{
(E)-N-(3,4-dimethylisoxazol-5-yl)-4-((4-hydroxy-2-oxo-2H-chr omen-3-yl) diazenyl)Benzenesulfonamide; A New Synthetic Anti-Herpetic Agent for HSV-1
}

\author{
Ashish Kumar ${ }^{1, *}$, Brij Kishore Tiwari ${ }^{1}$, Mamta Mishra ${ }^{1}$, Navneet Kumar $^{2}$ \\ ${ }^{1}$ Department of Applied Science \& Humanities, G.L. Bajaj Institute of Technology \& Management, Greater \\ Noida-201308, India \\ ${ }^{2}$ Department of Applied Science \& Humanities, Inderprastha Engineering College, Ghaziabad, India
}

*Author to whom correspondence should be addressed:

E-mail:ashish2009chemistry@gmail.com

(Received November 9, 2020; Revised March 18, 2021; accepted April 9, 2021).

\begin{abstract}
E)-N-(3,4-dimethylisoxazol-5-yl)-4-((4-hydroxy-2-oxo-2H-chromen-3-yl)diazenyl)b enzene sulfonamide (HDF) was prepared by condensation of 4-hydroxy coumarin and 4-amino-N-(3,4-dimethylisoxazol-5-yl)benzene sulfonamide (sulphafurazole). The structure of synthesized compound was established using IR, ${ }^{1} \mathrm{H}$ and ${ }^{13} \mathrm{C}-\mathrm{NMR}$ spectral analysis. On evaluation of in-vitro anti-herpetic activity of this compound against $H S V$ - 1 , compound was found able to inhibit viral replication at late stages of infection by inhibiting the replication of HSV-1. This anti herpetic nature of HDF was evidenced by the reduction of specific gene products $\beta$-(ICP-6) and $\gamma$-(ICP-5 and gB) groups in western blotting.
\end{abstract}

Keywords: coumarin-sulphonamide, 4-hydroxy coumarin, HSV-1, immunoblot analysis, post infection

\section{Introduction}

Herpes Simplex Virus type-1 (HSV-1), an associated member of herpes viridae community, is an enveloped DNA virus that causes many types of contagious viral infections like cold sores. ${ }^{1)}$ It is possible to prevent viral infection by administration of the vaccine, which is an antibody required for the organism's immune system to detect the virus or treat the disease. Some types of infections, such as $H S V$ type- 1 for which no vaccines are available, requiring the development of antiviral agents. ${ }^{2)}$

Various chemical substances are admissible to treat the infections begetted by Herpes Simplex Virus type- 1 and for medication of such viral infections. Acyclovir (ACV) and its nucleoside derivatives such as Paniciclovir, Valacyclovir and Famiciclovir are used. The mechanism of these antiviral agents is stationed on the inhibition of DNA polymerase enzyme of virus, which avert the replication of DNA of virus. ${ }^{3)}$ Usually these antiviral agents require activation by phosphorylation which is relying on viral and kinases of host cell and capable to eliminate replication of virus in host cell. ${ }^{4)}$ The long time uses of these compounds as antiviral agents can show the possibility to develop the immunity by virus for these chemical compounds. ${ }^{5)}$ These limitations therefore highlight the need to develop new anti-HSV agents based on alternative mechanism of action.
Some synthetic and natural coumarin (2H-1-benzopyran-2-one) derivatives have outstanding chemical reactivity and bioactivities and they are able to show a paramount role to amend various viral infections. ${ }^{6)}$

4-Hydroxy coumarin and its various derivatives has proven a central ingredient in fabrication of an efficacious anti-coagulant drug named as Warfarin. The addition of aryl group to carbon of 4-hydroxy coumarin moiety is vastly pronounced in demonstrating capacious biological actions namely antiviral ${ }^{7)}$ and antibacterial ${ }^{8)}$ activities. In previous studies the substitution of aryl or azo group in 4-Hydroxy coumarin moiety has been reported which indicates admirable antimicrobial activities. ${ }^{9)}$ Some thiazole, pyridine, triazole and phenyl thiazole derivatives of 4-hyroxy coumarin was synthesised by J. Sahoo et al and evaluate their in-vitro antibacterial activities against patogens. ${ }^{10)}$

A Sabt et al. synthesized coumarin-6-sulfonamide derivatives and investigated their anti-proliferative nature and conclude that all synthesized compounds was able to diminish the growth of cancer cell by blocking topoisomerase-2 enzyme while doxorubin used as reference drug. ${ }^{11)}$ So it can be stated that coumarin-sulphonamide derivatives can be acts as a compounds of biological interest. ${ }^{12)}$

Present paper focus on the synthesis of 
coumarin-sulphonamide derivative by reaction with 4-hydroxy coumarin and sulphafurazole. The structure of synthesized compound established by using Infrared, ${ }^{1} \mathrm{H}$ and ${ }^{13}$ C-N.M.R. spectroscopic methods and evaluation of it's in-vitro antiviral activity against HSV-1 along with determination of its $\mathrm{CC}_{50}$ and $\mathrm{EC}_{50}$ value

\section{Material and Methods}

Sodium nitrite, Sulphafurazole, 4-hydroxy coumarin, and sodium hydroxide, hydrochloric acid, methanol, ethanol and Isopropanol, Dulbeco modified Eagle medium, Fetal Bovine Serum, Phosphate Buffer Saline, Glutamine, Sodium pyruvate, Penicillin and Streptomycin used in synthesis were purchased from Sigma Aldrich. All solvents were purified by distillation method. Lymph Buffer solution, Phenyl methacophenol Fluoride, Triton Solution, Protein antibodies ICP-5,6,8, anti gb and $\beta$-actin were purchased from Merck-BDH.

Melting point was determined by open capillary method in sulphuric acid bath. Elemental analysis for new synthesized compound was performed on a Perkin-Elmer series-II, 2400 elemental analyzer. Infra-Red spectra was recorded using Nucon IR spectrophotometer using potassium bromide pellets.

The ${ }^{1} \mathrm{D} \&{ }^{2} \mathrm{D}{ }^{1} \mathrm{H}$ and ${ }^{13} \mathrm{C}-\mathrm{N}$.M.R spectra were recorded by using Bruker Avance 500 spectroscope. Mixture of $\mathrm{CDCl}_{3}$ and DMSO- $\mathrm{d}_{6}$ was used as solvent and TMS as reference compound. The chemical shifts of synthesized compound were delineated on $\delta$ scale/ppm.

\section{Synthesis of HDF}

4-(chlorodiazenyl)-N-(3,4-dimethylisoxazole-5-yl)ben zenesulphonamide (II) was obtained by adding $3 \mathrm{mMol}$ (0.207 gram) cold aqueous solution of sodium nitrite added in acidic solution of $3 \mathrm{mMol}$ (0.801gram) 4-amino-N-(3,4-dimethyl-isoxazol-5-yl) benzene sulphonamide (Sulphafurazole) (I) in ice bath at $5^{\circ} \mathrm{C}$ temperature.

Further mix this solution with $20 \mathrm{~mL}$ alkaline solution of 4-hydroxy coumarin (III) which prepared by dissolving 3mMol (0.545 gram) 4-hydroxy coumarin in $20 \mathrm{~mL}$ of $15 \%$ lye solution. Whole mixture was placed in ice bath for 45 minute at $5^{\circ} \mathrm{C}$. Pale yellow crystal of (E)-N-(3,4-dimethylisoxazol-5-yl)-4-((4-hydroxy-2-oxo2H-chromen-3-yl)diazenyl)benzene sulfonamide (HDF) (IV) was filtered and washed with demineralized water. $^{13)}$ (Scheme-1)

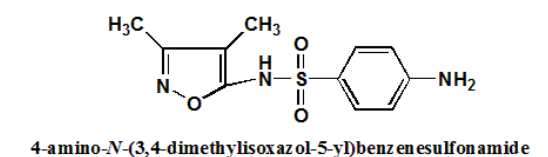

4-amino- $N$-(3,4-dimethylisox az ol-5-yl)benz en esulfon amid
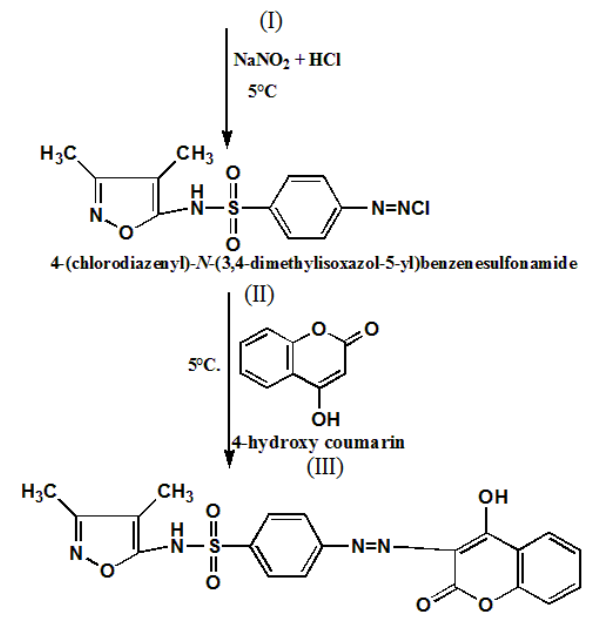

(E)-N-(3,4dim ethylisoxazol-5-yl)-4-((4-hydroxy-2-oxo-2H-chromen-3-yl)diazenyl)b enzenesulfonamid

Scheme 1 Synthetic route for preparation of HDF

\subsection{Microanalysis of HDF}

Pale Yellow crystal, Melting point $235-241^{\circ} \mathrm{C}$, Yield (80\%), Analysis for $\mathrm{C}_{20} \mathrm{H}_{16} \mathrm{~N}_{4} \mathrm{O}_{7} \mathrm{~S}$ (molar mass 456) Calculated \% $\mathrm{C}=52.63, \mathrm{H}=3.53, \mathrm{~N}=12.28, \mathrm{~S}=7.03$, $\mathrm{O}=24.54$, Found $\% \mathrm{C}=52.83, \mathrm{H}=3.51, \mathrm{~N}=12.26, \mathrm{~S}=$ $7.02, \mathrm{O}=24.56$, Soluble in DMSO, Acetone, $\mathrm{m} / \mathrm{z}=456$ (100\%), 457 (4.9\%), 458 (3.9\%) , 459 (1.1\%),

IR Spectral data: $3435-3438 \mathrm{~cm}^{-1}$ (-NH group), $3179-3180 \mathrm{~cm}^{-1} \quad$ (-OH group), $1689 \mathrm{~cm}^{-1} \quad(-\mathrm{C}=\mathrm{O}$ of Lactone carbonyl), $1272 \mathrm{~cm}^{-1}(\mathrm{O}-\mathrm{C}=\mathrm{O}$ of coumarin), $1585 \mathrm{~cm}^{-1}(-\mathrm{N}=\mathrm{N}-), 1129 \& 1302 \mathrm{~cm}^{-1}$ (symmetric and asymmetric vibration of $\mathrm{SO}_{2}$ group), $1647 \mathrm{~cm}^{-1}$ (methoxazole ring).

The ${ }^{1}$ H-N.M.R spectroscopic data of HDF which numbered as Figure-1, show the presence of one broad singlet at downfield value $4.0 \mathrm{ppm}$ for proton adjacent with nitrogen of $-\mathrm{SO}_{2} \mathrm{NH}$ - moiety present in $\mathrm{HDF}$. The doublet of doublet appeared in aromatic region at 7.91 $(2 \mathrm{H}, J=6.6,1.8,0.5 \mathrm{~Hz}$ ) ascribed to $\mathrm{H}-17$ and $\mathrm{H}-13$ show meta coupling with each other, likewise a new doublet of doublet appeared at $7.51(2 \mathrm{H}, J=6.6,1.8,0.5$ $\mathrm{Hz}$ ) due to $\mathrm{H}-16$ exhibiting meta coupling with $\mathrm{H}-14$. Moreover two sharp singlet of three protons embarked at downfield value $2.27 \mathrm{ppm}$ and $2.25 \mathrm{ppm}$ assigned to two methyl group existent in compound and the existence of all these characteristic proton signals reveals the presence of $\mathrm{N}$-(3,4-dimethyl isoxazol-5-yl)benzene sulphonamide moiety in HDF. Further sharp singlet of single proton appeared at $15 \mathrm{ppm}$ represents -OH group while four doublet of doublet appeared at $7.59 \mathrm{ppm}$ ( $J=$ 8.3, 1.3, $0.5 \mathrm{~Hz}$ ), $7.52 \mathrm{ppm}(\mathrm{J}=8.3,7.3,1.5 \mathrm{~Hz}), 7.59$ $\operatorname{ppm}(J=8.3,1.3,0.5 \mathrm{~Hz})$ and $8.13 \mathrm{ppm}(J=7.2,1.6$, $0.5 \mathrm{~Hz}$ ) assigned to $\mathrm{H}-26, \mathrm{H}-27, \mathrm{H}-28$ and $\mathrm{H}-29$ of hydroxy coumarin ring present in HDF. (Figure-2) 
<smiles>Cc1noc(NS(=O)(=O)c2ccc(/N=N/c3c(O)c4ccccc4oc3=O)cc2)c1C</smiles>

Fig.1:Numbering of HDF

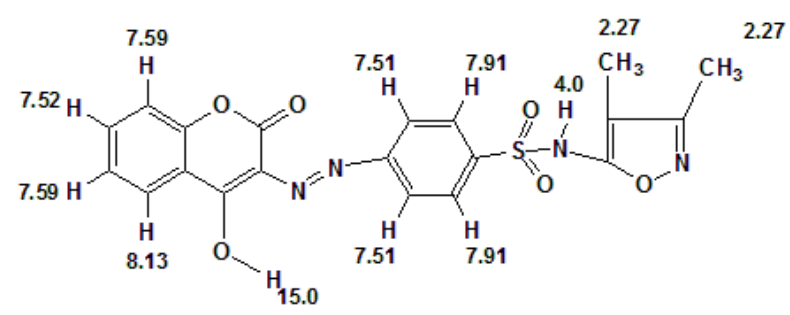

Fig.2: ${ }^{1} \mathrm{H}-\mathrm{NMR}$ chemical shift ( $\left.\delta / \mathrm{ppm}\right)$ of HDF

The ${ }^{13} \mathrm{C}-\mathrm{NMR}$ spectroscopic analysis of HDF (Figure-3) show signal of 20 carbon atom appeared at 159.9, 100.5, 158.9 ppm ascribed to C-3, C-4 and C-5 atom of $\mathrm{N}$-(3,4-dimethyl isoxazole-5-yl)benzene sulphonamide moiety and two sharp singlet appeared at 11.1 and $7.5 \mathrm{ppm}$ that two methyl group substituted on C-3 and C-4 of such group. Aromatic carbon signal appeared at $139.7 \mathrm{ppm}$ (C-12), $127.3 \mathrm{ppm}$ (identical C-13 and C-17 atom), 129.1 ppm (identical C-14 and $\mathrm{C}-16$ atom) and $131.9 \mathrm{ppm}$ (C-15) assigned to $\mathrm{N}$-(3,4-dimethyl isoxazol-5-yl)benzene sulphonamide moiety present in HDF . The carbon signal appeared at 164.9 ppm (C-20), 156.2 ppm (C-21), 150.2 ppm (C-23), 117.5 ppm (C-24), 82 ppm (C-25), 121.5 ppm (C-26), 128.4 ppm (C-27), 125.5 ppm (C-28) 126.5 ppm (C-29) strongly suggested the presence of 4-hydroxy coumarin ring in HDF which was further confirmed by ${ }^{1} \mathbf{H}-{ }^{13} \mathbf{C}-H S Q C$ spectrum

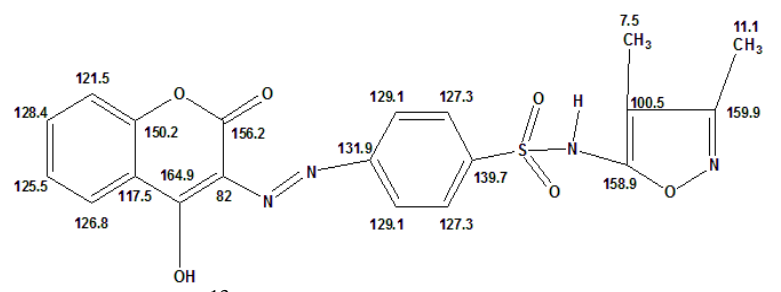

Fig.3: ${ }^{13} \mathrm{C}-\mathrm{NMR}$ chemical shift ( $\left.\delta / \mathrm{ppm}\right)$ of HDF

${ }^{1} \mathbf{H}-{ }^{1} \mathbf{H}$ COSY spectra of HDF show all ${ }^{1} \mathrm{H}-{ }^{1} \mathrm{H}$ scalar coupling which is more significant being $\mathrm{H}-13 \leftrightarrow \mathrm{H}-17$, $\mathrm{H}-14 \leftrightarrow \mathrm{H}-16, \mathrm{H}-26 \leftrightarrow \mathrm{H}-28$ and $\mathrm{H}-27 \leftrightarrow \mathrm{H}-29$ and all protons of $-\mathrm{CH}_{3}$ group (Figure-4)

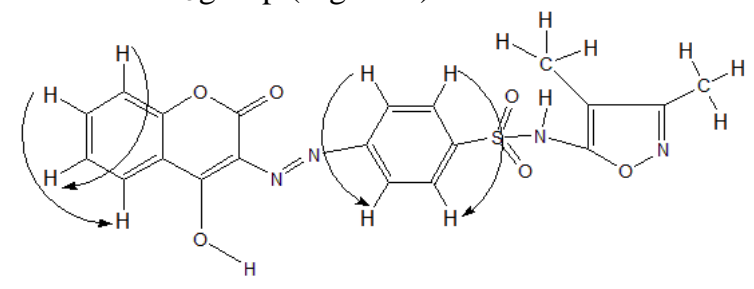

Fig.4: ${ }^{1} \mathrm{H}-{ }^{1} \mathrm{H}$ coupling in $\mathrm{HDF}$
The ${ }^{1} \mathbf{H}-{ }^{13} \mathbf{C}$ HSQC spectra of HDF show that out of twenty carbon atom, nine carbon atom were associated with coumarin ring, six were associated with benzene sulphonamide moiety and other five were of 3,4-dimethylisoxzole moiety present in HDF. Such spectra show coupling of $\mathrm{H}-13\left(\delta_{\mathrm{H}} 7.91\right)$ with $\mathrm{C}-13\left(\delta_{\mathrm{C}}\right.$ 127.3), H-14 $\left(\delta_{\mathrm{H}} 7.51\right)$ with $\mathrm{C}-14\left(\delta_{\mathrm{C}} 129.1\right), \mathrm{H}-16\left(\delta_{\mathrm{H}}\right.$ 7.51) with C-16 $\left(\delta_{\mathrm{C}} 129.1\right), \mathrm{H}-17\left(\delta_{\mathrm{H}} 7.91\right)$ with $\mathrm{C}-17$ $\left(\delta_{\mathrm{C}} 127.3\right), \mathrm{H}-7_{\mathrm{a}}, \mathrm{H}-7_{\mathrm{b}}, \mathrm{H}-7_{\mathrm{c}}\left(\delta_{\mathrm{H}} 2.27\right)$ with C-7 $\left(\delta_{\mathrm{C}} 7.5\right)$, H-6 $6_{\mathrm{a}}, \mathrm{H}-6_{\mathrm{b}}, \mathrm{H}-6_{\mathrm{c}}\left(\delta_{\mathrm{H}} 2.27\right)$ with C-6 ( $\left.\delta_{\mathrm{C}} 11.1\right)$ in $\mathrm{N}$-(3,4-dimethyl isoxazol-5-yl)benzene sulphonamide moiety , while $\mathrm{H}-26\left(\delta_{\mathrm{H}} 7.59\right)$ with $\mathrm{C}-26\left(\delta_{\mathrm{C}} 121.5\right)$, $\mathrm{H}-27\left(\delta_{\mathrm{H}} 7.52\right)$ with C-27 $\left(\delta_{\mathrm{C}} 128.4\right), \mathrm{H}-28\left(\delta_{\mathrm{H}} 7.59\right)$ with C-29 ( $\left.\delta_{\mathrm{C}} 125.5\right), \mathrm{H}-29\left(\delta_{\mathrm{H}} 8.13\right)$ with C-26 $\left(\delta_{\mathrm{C}}\right.$ 126.8) in coumarin ring present in HDF, which was further confirmed by broad range correlation of $\mathrm{C}-\mathrm{H}$ shown in Figure-2. On analyzing the ${ }^{1} \mathbf{H}-{ }^{13} \mathbf{C}$ HMBC correlation (Figure-5) observe that $\mathrm{H}-26\left(\delta_{\mathrm{H}} 7.59\right)$ show cross peak with C-21 ( $\left.\delta_{\mathrm{C}} 156.2\right)$ and C-25 ( $\left.\delta_{\mathrm{C}} 82\right)$ further H-29 $\left(\delta_{\mathrm{H}} 8.13\right)$ show cross peak with C-20 $\left(\delta_{\mathrm{C}}\right.$ 164.9) and $\mathrm{C}-23\left(\delta_{\mathrm{C}} 150.2\right)$ and $\mathrm{H}-27\left(\delta_{\mathrm{H}} 7.52\right)$ cross peak with $\mathrm{C}-24\left(\delta_{\mathrm{C}} 117.5\right)$ in coumarin moiety present in $\mathrm{HDF}$, other long rang correlation of $\mathrm{H}-7_{\mathrm{a}}, \mathrm{H}-\mathrm{7}_{\mathrm{b}}, \mathrm{H}-\mathrm{7}_{\mathrm{c}}$ $\left(\delta_{\mathrm{H}} 2.27\right)$ with C-5 $\left(\delta_{\mathrm{C}} 158.9\right)$ and H-6 $6_{\mathrm{a}}, \mathrm{H}-6_{\mathrm{b}}, \mathrm{H}-6_{\mathrm{c}}\left(\delta_{\mathrm{H}}\right.$ 2.27) with $C-3 \quad\left(\delta_{C}\right.$ 159.9) and the existence of $\mathrm{N}$-(3,4-dimethyl isoxazol-5-yl)benzene-sulphonamide moiety was confirmed by long range coupling of $\mathrm{H}-8\left(\delta_{\mathrm{H}}\right.$ 4.0) with $\mathrm{C}-17\left(\delta_{\mathrm{C}} 127.3\right)$ and $\mathrm{H}-13\left(\delta_{\mathrm{H}} 7.91\right)$ with $\mathrm{C}-5\left(\delta_{\mathrm{C}} 158.9\right)^{14,15)}$

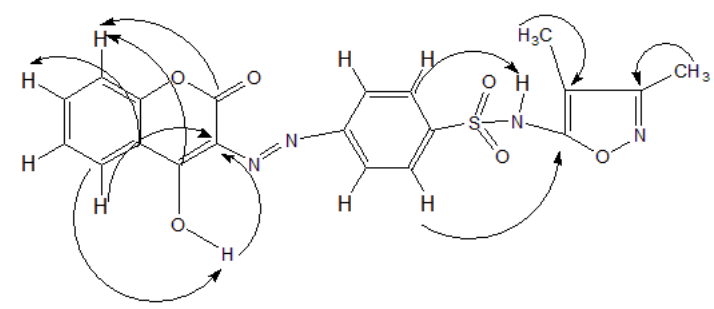

Fig.5: ${ }^{1} \mathrm{H}-{ }^{13} \mathrm{C}$ HMBC coupling in $\mathrm{HDF}$

\section{Evaluation of antiviral activity of HDF}

\subsection{Cell line, HSV-1 Culture and Extent of infection}

Sample Vero Cells of Cercopithecus aethiops were multiplied in Dulbecco modified Eagle Medium containing $10 \%$ fetal bovine serum and medium was supplemented in 2 mmole glutamine and 1 mmole sodium pyruvate alongwith antibiotic penicillin (100 unit $/ \mathrm{mL})$ and streptomycin $\left(100 \mu \mathrm{gmL}^{-1}\right)$. The viability of Vero cells were appraised by employing $0.02 \%$ Trypan blue exclusion assay. After infection all infected Vero cells were centrifuged to remove cellular debris and remaining viral titer was used to measure the plaques formed by using plaque number reduction method. ${ }^{16)}$

\subsection{Determination of $\mathrm{CC}_{50}$ value of $\mathrm{HDF}$}

Infected Vero cells of Cercopithecus aethiops were 
incubated with $\mathrm{HDF}$ at varied concentration of 01-500 $\mu \mathrm{gmL}^{-1}$ in Dulbecco's modified Eagle Medium for 24 hours and add $50 \mu \mathrm{L}$ volume of MTT solution with 100 $\mu \mathrm{L}$ of acidic solution of isopropanol (N/10 $\mathrm{HCl}$ dissolve in $10 \%$ isopropanol).

At room temperature after ensuring complete disposal of formazon crystals, all petri plates were placed in automatic plate reader at $690 \mathrm{~nm}$ with reference wavelength and $570 \mathrm{~nm}$ test wavelength and absorbance was observed. ${ }^{17)}$

$\mathrm{CC}_{50}$ value was narrated as drug concentration solicited to reduce the viability of cell up to $50 \%$

\subsection{Determination of $\mathrm{EC}_{50}$ value of $\mathrm{HDF}$}

Antivirucidal nature of HDF was determined by observing plaque count in supernatants of infected Vero cells by adopting plaque number reduction method. ${ }^{18)}$ Infected Vero cells after 60 minute of absorption at temperature of $37^{\circ} \mathrm{C}$ temperature, all the petri plates were douched with 5\% ethanol and growing medium was supersede with RPMI-1640 medium containing carboxymethyl cellulose $0.5 \%$ Fetal Bovine Serum and (30 $\left.\mu \mathrm{gmL}^{-1}\right) \mathrm{HDF}$ was added with Vero cells. After 24 hours incubation, carboxymethyl cellulose was discarded and monolayers were treated with $10 \%$ formaldehyde dissolve in Phosphate Buffer Saline and cells staining were performed by $1 \%$ methanolic solution of crystal violet indicator. The concentration of HDF required reducing virus yield up to $50 \%\left(\mathrm{EC}_{50}\right)$ was reckoned by regression analysis of the dose-response curves. Selectivity index value ${ }^{19)}$ of HDF was calculated by using the formula Selectivity Index Value (SI Value) = $\mathrm{CC}_{50}$ Value/EC 50 Value

\subsection{Evaluation of Synergistic activity of HDF with Acyclovir}

In synergistic study of HDF and Acyclovir minimum inhibitory concentration (EC value) of Acyclovir (0.5 $\mu \mathrm{gmL}^{-1}$ ) and $2.5 \mu \mathrm{gmL}^{-1}$ of HDF was used.

To observe the synergistic activity of HDF and ACV at post infection (p.i.), infected Vero cells were incubated with $\mathrm{HDF}$ and Acyclovir for 60 minute at $37^{\circ} \mathrm{C}$ temperature. After centrifugation supernatants of infected Vero cells were separate out and used to observe the plaques while non treated infected Vero cells (CTR) were used as reference. ${ }^{20)}$

\subsection{Affectivity of HDF during various stages of HSV-1 infection}

To determine the effect of HDF at different stages of infection of HSV-1, half minimum effective concentration of HDF (25.98 $\left.\mu \mathrm{gmL}^{-1}\right)$ was added with Vero cells (i) before infection induced by HSV-1 (ii) during the adsorption period for 1 hour (iii) Immediately after the adsorption of HSV-1. In all steps Vero cells were incubated in RPMI supplemented 2\% concentered solution of PBS for 24 hour by maintaining temperature $37^{\circ} \mathrm{C}$ and supernatants of infected Vero cells were used to identify the affectivity of HDF as antiviral agent. ${ }^{21)}$

\subsection{Assessment of anti-viral nature of HDF at early stages of post infection}

Vero cells matured in 24-well plates induced an infection by HSV-1(0.1 m.o.i) and incubated for 2 hour at $4^{\circ} \mathrm{C}$. Further infected Vero cells were washed by phosphate buffered saline to remove viral debaris. 25.98 $\mu \mathrm{gmL}^{-1}$ concentration of HDF was supplemented with infected Vero cells at various times of post infection for 0-1 hour, 1-3 hour, 4-6 hour and 6-8 hour. After this specified time lap the supernatants of untreated infected Vero cells and HDF treated infected cells were recovered and to assess anti herpetic behavior of HDF by plaque number reduction assay.

\subsection{Assessment of antiviral nature of HDF at late stages of post-infection}

To evaluate the conseiences HDF on viral replication at post infection, firstly Vero-cells were incubated with $\mathrm{HSV}-1$ at $37^{\circ} \mathrm{C}$ temperature for 5-6 minute to allow virus to penetrate Vero cell membrane and allow replication of virus for 24 hours. Infected Vero cells were treated with $25.98 \mu \mathrm{gmL}^{-1}$ concentration of HDF for $0-24$ hour, 15 minute-24 hour, 45 minute-24 hour, 2-24 hour, 3-24 hour and 4-24 hour while untreated Infected Vero cells (CTR) were used as control. ${ }^{22)}$

\subsection{Western Blotting Analysis}

To explore the attribute of HDF to intrupt protein expression of HSV-1, western blotting technique was employed. ${ }^{24,25)}$ Vero cells, previously washed with phosphate buffer saline centrifuged for 15 minutes and pellets were adjourned in cold lymph buffer solution containing $10 \mathrm{mM}$ phenyl methacophenol fluoride phosphatase as inhibitor mixture along with $2 \%$ triton solution, incubated for 30 minutes at $0^{\circ} \mathrm{C}$ temperature and supernatants were arrassed to negotiate protein expression. The protein contents were aloofed by gel electrophoresis technique in $10 \%$ S.D.S. polyacrylamide and electroblotted on to nitrocellulose membrane. After blocking the membrane using $10-12 \%$ dry fat free milk suspended in tris-buffer solution and $0.5 \%$ solution of twin-20 for 60 minute at $25^{\circ} \mathrm{C}$ temperature, incubated with $1 \mathrm{gm} / \mathrm{mL}$ anti ICP-5, anti ICP-6, anti ICP-8, anti-gb anti $\beta$-actin antibodies (control for protein loading). Later on washing membranes were incubated for 60-70 minute with secondary antibodies conjugated with horseradish perioxidaste band of protein were appearent by ECL plus detection system by following instruction manualed by manufacturer and densitometry data for the blots were analysed with help of imagJ software. 


\section{Result and Discussion}

The cytotoxicity of HDF was represented by dose response curve between cell viability percentage versus varied concentration of HDF. (Figure : 6)

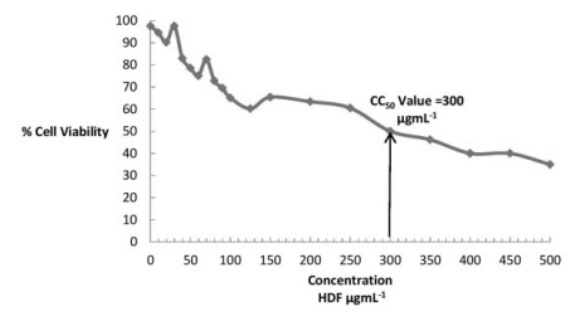

Fig.6:Determination of $\mathrm{CC}_{50}$ value of HDF.

During experiment, no substantial changes in cell count were observed up to $200 \mathrm{\mu gmL}^{-1}$ concentration of HDF which evidenced by trypan blue staining. HDF start to show a toxic effect on the viability of Vero cells after $300 \mu \mathrm{gmL}^{-1}$ till the highest dose used in experiment.

Curve in Figure-7 shows the half maximum effective concentration value (EC $\mathrm{E}_{50}$ value) of HDF against HSV-1 strain. Such Graph indicates at $3.69 \mu \mathrm{gmL}^{-1}$ concentration of HDF, the percentage of plaque formation start to reduce.

For the reduction of $50 \%$ of plaques, the required concentration of compound was $25.98 \mu \mathrm{gmL}^{-1}$.

The efficacy of HDF as an antiviral compound can be expressed by the selectivity index value (S.I. value). The S.I. value of HDF was 11.54 which was greater than 10 which ensures that HDF can act as a potential antiviral agent.

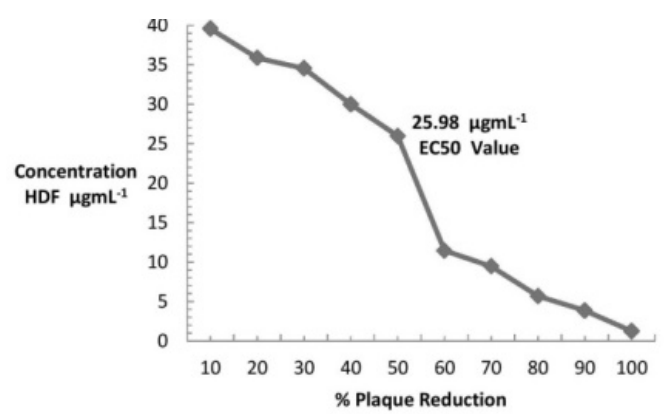

Fig. 7:Determination of EC50 value of HDF
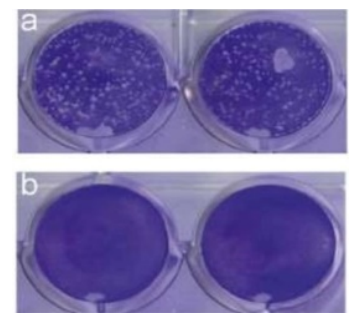

Fig.8:Effect of HDF on viral plaque of HSV-1 (a) Viral plaques in absence of HDF (b) Viral plaques in presence of HDF

It was observed by synergistic action of HDF with Acyclovir that $0.5 \mu \mathrm{gmL}^{-1}$ quantity of Acyclovir was enough to inhibit HSV-1 replications nearly 48 percent as compared with CTR and almost alike inhibition was monitored in Vero cells treated with $2.5 \mu \mathrm{gmL}^{-1}$ concentration of HDF. (Figure-9)

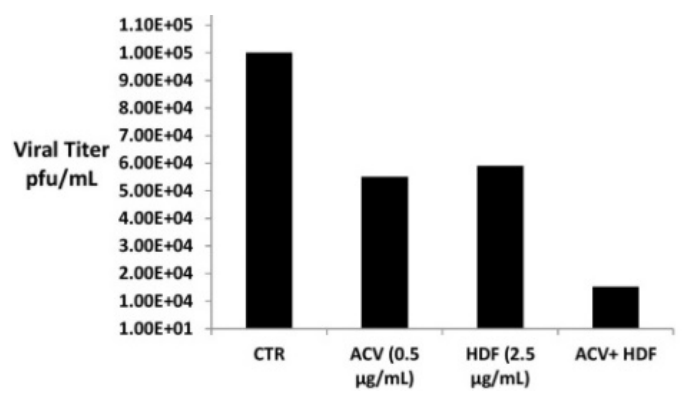

Fig.9:.Synergistic antiviral activity of HDF and Standard drug Acyclovir

On observing the effectivity of HDF at different stages of HSV-1 induced infection, that HDF not show any inhibitory action on replication of virus during adsorption period meanwhile after the penetration of virus it show successive increment of extent of inhibition with time. Such result suggested that HDF can act as antiherpetic agent for HSV-1 induced infection at post infection. The inhibitory action of HDF was confirmed when infected Vero cells were treated with compound at different time of post infection (for 0-24 hour, 15 minute-24 hour, 45 minute-24 hour, 2-24 hour, 3-24 hour and 4-24 hour) (Figure 10 \& 11)

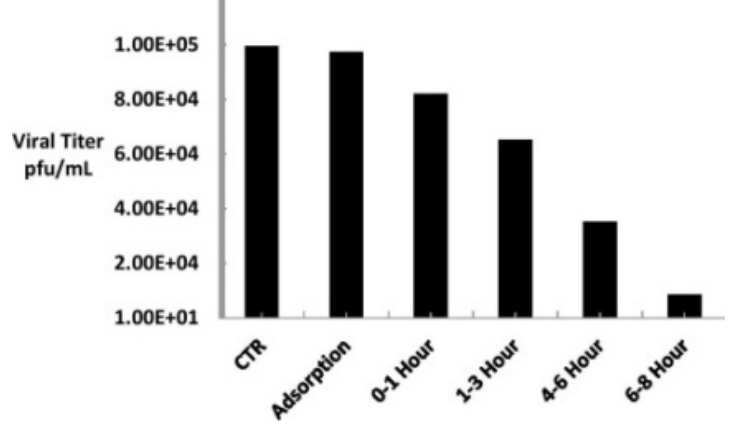

Fig.10:Antivirucidal effect HDF on Viral replication during adsorption period and at initial and different time of post infection (p.i.) at 0-1 hour, 1-3 hour, 4-6 hour and 6-8 hour

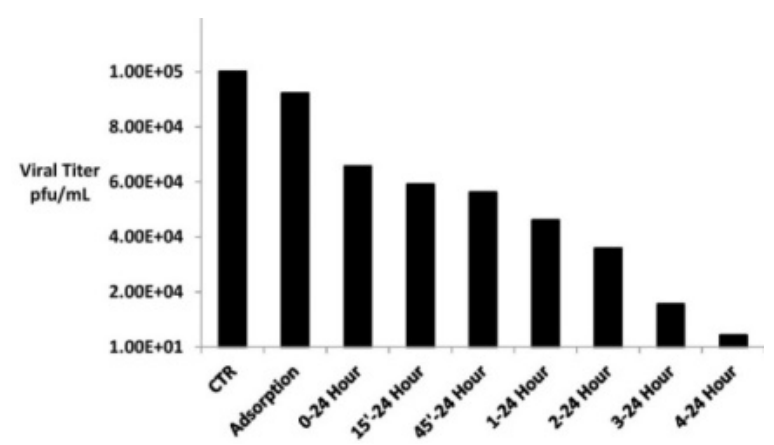

Fig.11:Antivirucidal effect of HDF on adsorption period and different time of post infection

The result demonstrated by western blot analysis (Figure-12) indicates that $\beta$-(ICP-6) and $\gamma$-(ICP-5 and gB) protein expression of $\mathrm{HSV}-1$ was reduced 
remarkably in Vero cells which were treated with HDF but $\alpha$-(ICP-8) show partial reduction.

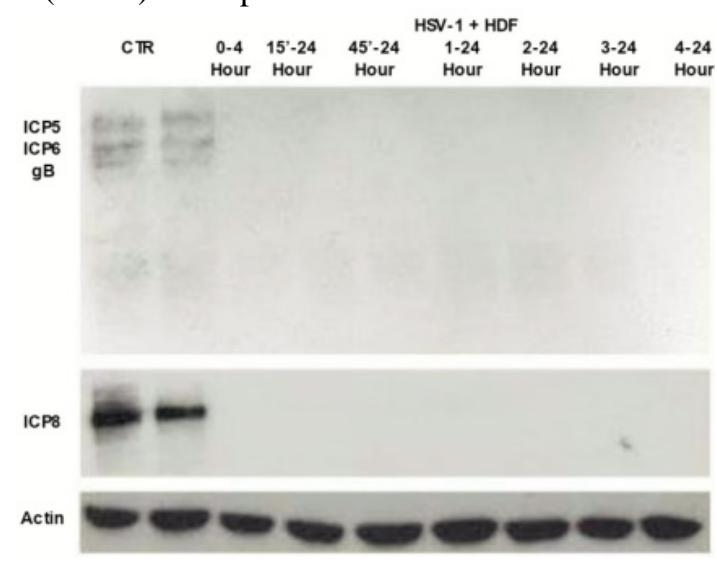

Fig.12:western blot analysis of HDF

\section{Conclusion}

Our finding suggested that compound ((E)-N-(3,4-dimethylisoxazol-5-yl)-4-((4-hydroxy-2-oxo -2H-chromen-3-yl)diazenyl)benzenesulfonamide act as antivirucidal agent against $H S V-1$ evidenced by its good selectivity index (SI value $=11.54$ ) and lesser toxicity. This compound is less able to inhibit the viral replication during the adsorption period but it can inhibit such replication at post infection. In western blotting analysis the reduction of specific gene products $\beta$-(ICP-6) and $\gamma$-(ICP-5 and gB) groups strongly recommended that HDF can able to inhibit HSV-1 replication in host cell by blocking virus DNA synthesis at late stage of infection.

\section{Acknowledgements}

All the authors are highly thankful to Dr. R. G. Sharma, former Principal \& Head, Department of Chemistry, N.A.S. College, Meerut (U.P.) India for the valuable suggestion during whole research work.

\section{Nomenclature}

\begin{tabular}{|l|l|}
\hline$A C V$ & acyclovir \\
\hline$C C_{50}$ & $50 \%$ cytotoxic concentration \\
\hline$H S V-1$ & herpes simplex virus type-1 \\
\hline$E C_{50}$ & half minimum effective concentration \\
\hline$M O I$ & multiplicity of infection \\
\hline$P f u$ & plaque forming unit \\
\hline$S I$ & selectivity index \\
\hline$C T R$ & untreated infected Vero cells \\
\hline
\end{tabular}

\section{References}

1) Aldrin Man, Mark Slevin, Eugen Petcu \& Cornel Fraefel,"The Cyclin-Dependent Kinase 5 Inhibitor Peptide Inhibits Herpes Simplex Virus Type 1
Replication”, Scientific Reports, 9 (1260) 1-8 (2019). doi.org/10.1038/s41598-018-37989-3

2) Pamela Chayavichitsilp, Joseph V Buckwalter, Andrew C Krakowski, “Herpes simplex”, Pediatrics in Review, 30 (4)119-129(2009). doi: 10.1542/pir.30-4-119

3) Erik De Clercq, "Selective Antiherpes virus agents", Antiviral Chem. \& chemotherapy, 22 93-101 (2013). doi.org/10.3851/IMP2533

4) Scott H James and Mark N Prichard , "Current and future therapies for herpes simplex Virus infections: Mechanism of action and drug resistance”, Curr. Opin. Virology, 8 54-64 (2014). doi: 10.1016/J.coviro.2014.06.003

5) Angela Stefanachi, Francesco Leonetti, Leonardo Pisani, Marco Catto \& Angelo Carotti , "Coumarin: A Natural, Privileged and Versatile Scaffold for Bioactive Compounds” , Molecules, 23 (2) 250 (2018). doi: 10.3390/molecules23020250

6) F. Borgess, N Roleria, I Mulhazes Santana, E. Uriate, "Simple coumarins and analogues in medicinal chemistry, Occurance, synthesis and Biological activity”, Curr. Med. Chem. 12 (8)887-916 (2005) doi: 10.2174/0929867053507315.

7) B. Serge Kirkiacharian, Erik De Clercq, Raffi KurkJian, "New synthesis and anti-HIV and antiviral properties of 3-arylsulfonyl derivatives of 4-ydroxycoumarin and 4-hydroxyquinolone”,Pharm Chem J., 42, $265 \quad$ (2008). doi.org/10.1007/s11094-008-0103-0

8) SB Diwakar, B Govindh, Y Nagendra Sastry, "Synthesis, X-ray characterization and biological evaluation of some new 2-(4-methy-2-oxo-2H-chromen-7yloxy)acetamide derivatives”, Med. Chem. Res. 24(4) 1546-1557 (2015). doi:10.1007/s00044-014-1230-7

9) O. Nagaraja, D. Bodke Yadav, PushPavathi Itte "Synthesis, characterization and biological investigations of potentially bioactive heterocyclic compounds containing 4-hydroxy coumarin”, Heliyon, 6 (6)(2020) 1-11. doi: 10.1016/J.heliyon.2020.e04245

10) J. Sahoo, Makeap Kumar \& Sudhir Kumar "Synthesis, spectral characterization of some new 3-heteroaryl azo-4-hydroxy coumarin derivatives and their antimicrobial evaluation”, J.of Taibah University for Science 9 187-195 (2015). doi.org/10.1016/J.Jtusci.2014.08.001

11) Ahmed Sabt, O.M. Abdelhofer, R.S. El-Hagger "Novel coumarin-6-sulfonamides as apoptotic antiproliferative agents: synthesis, in vitro biological evaluation, and QSAR studies”, J. of Enzyme Inhibition \& Medicinal Chem 33(1)1095-1107 (2018). doi.org/10.1080/14756366.2018.1477137

12) Mohd. Zaheen Hassan, Hasnati Osman and Mohd. Jawed Ahsan, "Therapeutic potential of coumarins 
as antiviral agents, Eur. J. Med. Chem". 123(10) 236-255 (2016). doi: 10.1016/J.ejmech.2016.07.056

13) M.R. Yazdanbakhsh, A. Ghanadzadeh, E. Moradi, "Synthesis of some new azo dyes derived from 4-hydroxy coumarin and spectrometric determination of their acidic dissociation constants", J molecular liquids 136 165-168 (2007). doi: 10.1016/J.molliq.2007.03.005

14) Davorka Zavrsnik , Samija Muratović, Damjan Makuc Janez Plavec, "bis-(4-Hydroxycoumarin) and Benzopyrano- Coumarin Derivatives: Synthesis, ${ }^{1} \mathrm{H} /{ }^{13} \mathrm{C}-\mathrm{NMR}$ Conformational and X-ray Crystal Structure Studies and In Vitro Antiviral Activity Evaluations”, Molecules 16, 6023-6040 (2011). doi: 10.3390/molecules16076023

15) Neda mostajeran, Farzaneh Amin Arshad, Hamid Aliyan and Ahmad Reza Mass, "Solvent free synthesis and antibacterial evaluation of novel coumarin sulfonamides”, Pharmaceutical Chemistry Journal, $52 \quad$ (1) 1-6 (2018). doi: 10.1007/s11094-018-1756-y

16) Ito Kazuhide, Micro and Macro scale measurement of fungal growth under various temperature and humidity condition, Evergreen, 1 (1) 32-39 (2014)

17) $M$ Wahid, M. Noor, H. Hara,Recombinant Moringa Oleifera Lectin produced in Pichia Pastoris is a Potential Natural Coagulant Evergreen, 3 11-16 (2016)

18) L Boff, IT Silva, DF Argenta, LM Farias, "Strychnos pseudoquina A. St. Hil.:a Brazilian medicinal plant with promising in vitro antiherpes activity”, J Appl Microbiol, 121 (6) 1519-1529 (2016) . doi.org/10.1111/Jam.13279.

19) L Boff, J Munkert, FM Ottoni, NFZ Schneider, GS Ramos, "Potential anti-herpes and cytotoxic action of novel semisynthetic digitoxigenin-derivatives" Eur $J \quad$ Med Chem $167 \quad 546-561$ (2019).doi.org/10.1016/J.eJmec h.2019.01.076

20) John F. Marcelletti, "Synergistic inhibition of herpesvirus replication by docosanol and antiviral nucleoside analogs”, Antiviral Res. 56 (2) 153-166 (2002). doi.org/10.1016/S0166-3542(02)00105-5

21) Livia Civitelli, Simona Panella, Maria Elena Marcocci, Alberto De Petris "In vitro inhibition of herpes simplex virus type 1 replication by Mentha suaveolens essential oil and its main component piperitenone oxide", Phytomedicine 21 857-865 (2014). doi: 10.1016/J.phymed.2014.01.013

22) ALF Larsson, "Mode of action, toxicity, pharmacokinetics and efficacy of some new antiherpesvirus Guanosine analogs related to Buciclovir", Antimicrobial Agent \& Chemotherapy,30 (4)598-605 (1986)

23) Arhiro Kano, Moes Kibunja Kamita, Tauma Iwasaki, Mitsuru Shindo, "Bongkrekic Acid Induces Selective cytotoxicity in tumer cells revealed by CCK-8”, Evergreen, 2/3 23-27 (2017)
24) M M Bradford, “A rapid and sensitive method for the quantitation of microgram quantities of protein utilizing the principle of protein-dye binding”. Anal Biochem. $72 \quad 248-254 \quad$ (1986). doi. org/10.1016/0003-2697(76)90527 -3

25) Laurita Boff, Naira Fernanda, Zanchett Schneider, Jennifer Munkert, Flaviano Melo Ottoni, "Elucidation of the mechanism of anti-herpes action of two novel semisynthetic cardenolide derivatives", Archives of Virology $165 \quad$ 1385-1396 (2020) .doi.org/10.1007/s00705-020-04562-1 